\title{
Nuclear Factor-kB Activation: A Question of Life or Death
}

\author{
Shishir Shishodia and Bharat B. Aggarwal* \\ Cytokine Research Section, Department of Bioimmunotherapy, The University of Texas M. D. \\ Anderson Cancer Center, Box 143, 1515 Holcombe Boulevard, Houston, Texas 77030
}

Received 8 November 2001

\begin{abstract}
Apoptosis is a mode of cell death that plays an important role in both pathological and physiological processes. Research during the last decade has delineated the entire machinery needed for cell death, and its constituents were found to pre-exist in cells. The apoptotic cascade is triggered when cells are exposed to an apoptotic stimulus. It has been known for several years that inhibitors of protein synthesis can potentiate apoptosis that is induced by cytokines and other inducers. Until 1996, it was not understood why protein synthesis inhibitors potentiate apoptosis. Then three reports appeared that suggested the role of the transcription factor NF- $\mathrm{KB}$ activation in protecting the cells from TNF-induced apoptosis. Since then several proteins have been identified that are regulated by NF-kB and are involved in cell survival, proliferation, and protection from apoptosis. It now seems that when a cell is attacked by an apoptotic stimulus, the cell responds first by activating anti-apoptotic mechanisms, which may or may not be followed by apoptosis. Whether or not a cell undergoes proliferation, the survival, or apoptosis, appears to involve a balance between the two mechanisms. Inhibitors of protein
\end{abstract}

*To whom correspondence should be addressed.

Tel: 713-792-3503/6459; Fax: 713-794-1613

E-mail: aggarwal@mdanderson.org

Abbreviations: NF- $\mathrm{BB}$, nuclear factor kappa B; TNF, tumor necrosis factor; IKB, inhibitory kappa B; TRADD, TNF receptor-associated death domain; NIK, NF-kB-inducing kinase; TRAF2, TNF receptorassociated factor 2; SOD, superoxide dismutase; RIP, receptor interacting proteins; SODD, silencer of death domain; FADD, Fas-associated death domain; FLICE, FADD-like ICE; c-FLIP, cellular FLICE inhibitory protein; LT, lymphotoxin; FasL, fibroblast associated ligand; TRAIL, TNF-related apoptosis-inducing ligand; DR3L, death receptor 3 ligand; TWEAK, weak homologue of TNF; THANK, TNF homologue that activates apoptosis, NF-kB and JNK; JNK, c-jun Nterminal kinase; VEGI, vascular endothelial cell growth inhibitor; cIAP, cellular inhibitors of apoptosis; PKR, double-stranded-RNAdependent protein kinase; MEKK-1, mitogen-activated protein kinase/extracellular signal-regulated kinase kinase 1. synthesis seem to suppress the appearance of protein that are involved in anti-apoptosis. The present review discusses how NF-kB controls apoptosis.

Keywords: NF- $\kappa B$, Apoptosis, Caspases, Reactive oxygen intermediates, TNF

An intricate balance between cell growth and cell death drives the proper growth, development, and function of most tissues (Jacobson et al., 1997). A vast amount of information has accumulated regarding the molecular mechanisms that govern cell growth, but the mechanisms by which cells regulate their own death still remains a matter of great intrigue, and have recently begun to acquire great importance.

One known mechanism, apoptosis, or programmed cell death, is a physiological process that is believed to be responsible for the deletion of unwanted cells during organ and tissue development, tissue homeostasis, and removal of self-reactive immune cells and pathologically induced tissue damage. Virus-infected cells are eliminated by the interaction with cytotoxic T-lymphocytes that kill the virus-infected cells by inducing apoptosis (Shibata et al., 1994; Darmon et al., 1995). Cells that have DNA damage undergo apoptosis so as to eliminate cells that have accumulated genetic mutations and may become cancerous (Jaattela, 1999; Stambolic et al., 1999). In addition to being activated during developmentrelated cell reduction, apoptosis can be triggered in many cell types by various stresses. These include chemotherapeutic agents, cytokines, ionizing radiation, osmotic stress, and expression of viral proteins such as E1A (Nagata, 1997).

In the last few years, extensive research has revealed that cell death, whether at the single cell level, the tissue/organ level, or the organism level, is as important to life as cell survival. The critical role of apoptosis has been recognized in a wide variety of situations. These include immunomodulation, autoimmunity, sepsis, arthritis, inflammatory bowel disease, chronic heart failure, periodontal diseases, allograft rejection, neovascularization, obesity, 
tumorigenesis, meningitis, and parturition (Aggarwal and Vilcek, 1992).

$\mathrm{NF}-\kappa \mathrm{B}$ is a ubiquitously expressed transcription factor that plays a pivotal role in the expression of various inducible target genes that regulate apoptosis among several other vital functions (Ghosh et al., 1998). It also controls cell proliferation, differentiation, and immune and inflammatory responses. This factor is a member of the Rel family of proteins, which bind to specific DNA sequences. In nonstimulated cells, the heterodimeric NF- $\mathrm{KB}$ complexes are sequestered in the cytoplasm of most cell types by inhibitory proteins of the IKB family (Beg and Baldwin, 1993). These inhibitors mask the NF- $\mathrm{KB}$ nuclear localization domain and inhibit its DNA-binding activity. In response to a large variety of stimuli, the $\mathrm{I} \kappa \mathrm{B}$ inhibitor is rapidly phosphorylated and degraded. This allows NF- $\kappa \mathrm{B}$ nuclear translocation, DNA binding to specific recognition sequences in promoters, and transcription of the target genes (Karin, 1999; Pahl, 1999). $\mathrm{Rel} / \mathrm{NF}-\kappa \mathrm{B}$ transcription factors are induced in response to a large variety of stimuli and regulate a number of genes. The $\mathrm{Rel} / \mathrm{NF}-\kappa \mathrm{B}$ transcription factor family is comprised of several structurally-related proteins that exist in organisms from insects to humans. The vertebrate family includes five cellular proteins-c-Rel, Rel A, RelB, p50/p105, and p52/p100. These proteins can form homodimers or heterodimers that give diverse combinations of dimeric complexes, which bind to DNA target sites, collectively called $\mathrm{\kappa B}$ sites, and directly regulate gene expression. The most common transcription factor of this family is called NF- $\kappa \mathrm{B}$, and consists of a p50/ RelA heterodimer. The different Rel/NF- $\kappa B$ proteins show distinct ability to form dimers, distinct preferences for different $\kappa \mathrm{B}$ sites, and distinct abilities to bind to I $\mathrm{B}$ inhibitor proteins (Chen and Ghosh, 1999). Thus, different Rel/NF-кB complexes can be induced in different cell types, and by distinct signals interact in distinct ways with other transcription factors and regulatory proteins, and regulate the expression of distinct gene sets.

\section{Mechanism of apoptosis}

Besides dying by necrosis, multicellular organisms can initiate a series of events that activate intracellular proteases and ultimately result in the destruction of the cell. These are collectively known as apoptosis. Apoptotic cells undergo an orderly series of biochemical or morphological events including cell shrinkage, mitochondrial breakdown, and nuclear DNA fragmentation (Arends et al., 1991). The dying cell degrades into subcellular membrane-bound vesicles called apoptotic bodies, which are ultimately removed by phagocytosis. Apoptosis is a molecular suicide program that is characterized by cytoplasmic shrinkage, nuclear condensation, and DNA fragmentation into 200-base pair fragments (Kerr $e t$ al., 1972; Cohen, 1993; Clarke and Clarke, 1995; Chinnaiyan and Dixit, 1996). It is a genetically regulated mechanism and its deregulation can result in multistep carcinogenesis
(McDonnell and Korsmeyer, 1991; Thompson, 1995; Gilmore et al., 1996)

Apoptosis is brought about by activation of a family of proteins known as caspases (cysteinyl, aspartate-specific proteases) (Cohen, 1997; Green, 2000). There are about 14 caspases that are involved in the process of apoptosis. Caspases are synthesized as proenzymes that are activated by proteolysis at two or three sites in order to remove the $\mathrm{N}$ terminal peptide and divide the proenzyme into large and small subunits, which in some cases are joined by a linker domain. The mature caspase is a heterotetramer of two large and two small subunits (Ceretti et al., 1992; Thornberry et al., 1992). All of the caspases are activated by cleavage at a specific aspartate residue and act in a cascade. They are ultimately responsible for the proteolysis of the cellular substrates that are responsible for apoptosis.

Poly (ADP-ribose) polymerase (PARP) is the most wellcharacterized substrate for several caspase in many cell systems. Intact PARP (116 kDa) is cleaved into two fragments (89 kDa and $24 \mathrm{kDa}$ ) during apoptosis (Kaufmann, 1989; Kaufmann, 1993). Cleavage of PARP is a valuable indicator of apoptosis, but its biological relevance is unknown. Caspaseactivated deoxyribonuclease (CAD) is a cytoplasmic endonuclease whose activation is thought to be responsible for generating the oligonucleosomal DNA fragments that are the hallmark of apoptosis (Enari et al., 1998).

DNA-dependent protein kinase (DNA-PK) is a DNA repair enzyme that is degraded during apoptosis by caspase 3 (Song et al., 1996). Degradation of DNA-PK will result in a decrease in the capacity of the cell to repair damage of nuclear DNA, thus facilitating the breakdown of DNA that is associated with apoptosis. Caspase 6 is responsible for the degradation of lamin, which are the major structural components of the nuclear envelope (Takahashi et al., 1996). Cleavage of the cytoskeletal proteins fodrin (Martin et al., 1995), Gas 2 (Brancolini et al., 1995), and actin (Mashima et al., 1995) during apoptosis may induce cell shrinkage and membrane blebbing, and alter cell signaling pathways. U1-70 kDa, a small ribonucleosomal particle that functions in the splicing of mRNA transcripts, is cleaved during apoptosis (CasciolaRosen et al., 1996). Caspases also cleave initiation factors (Antoku et al., 1997). This may inhibit translation during apoptosis. Caspases also cleave certain cell-signaling proteins, eg. PKC- $\delta$ and MEKK-1, which are rendered constitutively active and pro-apoptotic. In contrast, protein kinase B, which is involved in the anti-apoptotic pathway, is cleaved and inactivated by caspases (Widmann et al., 1998)

A cell is induced to undergo apoptosis, either by internal signals arising within the cells, or by external signals triggered by death activators that bind to receptors located at the cell surface. Internal signals initiate apoptosis in the mitochondria with the release of cytochrome c (Green and Reed, 1998; Susin et al., 1998). The mitochondrial pathway is controlled by the Bcl-2 family of proteins (Adams and Cory, 1998). There are 15 members of the Bcl-2 protein family that share 
homology in at least one of three conserved domains (BH1BH4). These may either promote survival (e.g., Bcl-2, $\mathrm{Bcl}-\mathrm{xL}$ ), or promote apoptosis (e.g., Bax, or Bak) (Gross et al., 1999). The Bcl-2 family of proteins register both positive and negative stimuli, and integrate them to determine whether the mitochondrial apoptotic pathway is turned on or off. Oncogenes encode mutated versions of the signaling proteins that control normal cell proliferation (e.g., Ras signaling). Another, the Raf oncoprotein, eventually initiates apoptosis when the cell receives an abnormal proliferative signal (Winston et al., 1996).

The apoptotic program can also be initiated by the action of extracellular messengers, termed death ligands. These bind to the cell-surface receptors, termed death receptors, that activate intracellular signaling events that begin an apoptotic cascade (Ashkenazi and Dixit, 1998; Sheikh and Fornace, 2000). Death receptors belong to the TNF receptor superfamily that is characterized by a cysteine-rich extracellular ligand-binding domain (Smith et al., 1994). Death receptors contain a consensus module known as the death domain that is found in the intracellular portion of the molecule, and is involved in transducing the apoptotic signal (Nagata, 1997). Fas and the TNF receptor are the two best-characterized death receptors, the cognate ligands for which are FasL and TNF, respectively.

Among all of the known physiological inducers of apoptosis in mammalian cells, the tumor necrosis factor (TNF) is perhaps the most potent and well studied. Many other members of the TNF superfamily also induce apoptosis. These include LT (lymphotoxin), FasL (fibroblast-associated ligand), TRAIL (TNF-related apoptosis-inducing ligand), DR3L (for death receptor 3 ligand or also known as TWEAK for a weak homologue of TNF), THANK (TNF homologue that activates apoptosis, NF- $\mathrm{BB}$ and JNK), and VEGI (vascular endothelial cell growth inhibitor) (Haridas et al., 1999; Mukhopadhyay et al., 1999). Whether all these TNF family members induce apoptosis by the same mechanism as TNF is unknown. Besides killer cytokines, outlined previously, apoptosis is also induced by various chemotherapeutic agents.

Within the last few years, a series of biochemical steps have been identified in the apoptotic pathway that is induced by cytokines and chemotherapeutic agents. For instance in TNFinduced apoptosis, the TNF receptor is activated. Through its cytoplasmic death domain, it recruits a protein called the TNF receptor-associated death domain (TRADD). It then sequentially recruits the Fas-associated death domain (FADD) and FADD-like ICE (FLICE, also called caspase-8) (Rath and Aggarwal, 1999; Darnay and Aggarwal, 1999; Wallach et al., 1999). The last activates caspase-9, which in turn activates caspase-3 (the executioner protease). This results in apoptosis.

In contrast to cytokines, chemotherapeutic agents induce cellular apoptosis by inducing the formation of mitochondrial transition pores, a rapid decrease in the mitochondrial transmembrane potential, and release of cytochrome $\mathrm{C}$. The latter, in the presence of the protein Apaf-1, activates caspase-
9, which then activates caspase-3. Recently, several studies have however suggested that these two receptor-mediated and non-receptor-mediated pathways that are initiated by cytokines and chemotherapeutic agents, respectively, are not exclusive of each other and share similar steps.

Most agents that induce apoptosis also activate NF- $\kappa B$. Thus, it is not too surprising that almost all of the cytokines of the TNF superfamily and chemotherapeutic agents activate NF- $\kappa B$. The TNF-induced activation of NF- $\kappa B$ (primarily consisting of p50 and p65 subunits) involves recruitment of the TNF receptor-associated factor (TRAF)-2 by TRADD, which then binds to NIK. TRADD also binds to the receptorinteracting protein (RIP). Either NIK or RIP then activate a kinase called the IKB $\alpha$ kinase (IKK), which in turn leads to the phosphorylation, ubiqutination, and degradation of $\mathrm{I} \kappa \mathrm{B} \alpha$ (the inhibitory subunit of $\mathrm{NF}-\kappa \mathrm{B}$ ), leading to $\mathrm{NF}-\kappa \mathrm{B}$ activation (Wallach et al., 1999). Some recent studies exclude NIK from a role in the TNF-induced NF- $\kappa B$ activation. How chemotherapeutic agents activate $\mathrm{NF}-\kappa \mathrm{B}$ is not fully understood, but most likely it also involves the phosphorylation, ubiqitination, and degradation of $\mathrm{I} \kappa \mathrm{B} \alpha$. The subject of this review is how NF- $\mathrm{BB}$ activation is linked with the induction of apoptosis by TNF and chemotherapeutic agents.

\section{Anti-apoptotic effects of NF-kB}

Almost five years ago it was shown that TNF-induced apoptosis can be blocked by NF- $\mathrm{KB}$ activation (Liu et al., 1996; Van Antwerp et al., 1996; Wang et al., 1996; Beg and Baltimore, 1996). Rel/NF- $\kappa \mathrm{B}$ transcription factors exercise their anti-apoptotic effects in a wide variety of cells to protect them from various apoptotic agents. They promote cell survival by inducing the transcription of anti-apoptotic genes (Fig. 1). Activation of NF- $\kappa \mathrm{B}$ either up-regulates the activity of anti-apoptotic genes, or down-regulates the activity of

\section{Anti-apoptotic NF-kB regulated gene products}

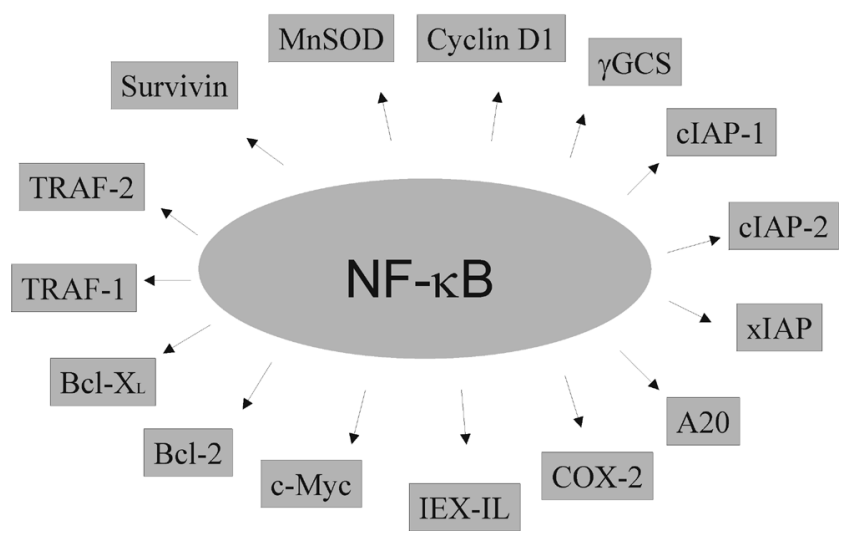

Fig. 1. Negative regulation of apoptosis by the NF- $\kappa B-$ regulated gene products. 
Table 1. Anti-apoptotic activity of NF- $\mathrm{KB}$

\begin{tabular}{|c|c|c|}
\hline Apoptosis Inducing agent & Cell Type & Reference \\
\hline \multirow[t]{16}{*}{ TNF } & MCF-7 & Liu et al., 1996 \\
\hline & HEF, Jurkat, T24 & Van Antwerp et al., 1996 \\
\hline & Rel A-/- fibroblasts and macrophages & Beg and Baltimore, 1996 \\
\hline & Prostate carcinoma cells & Herrmann et al., 1997 \\
\hline & Jurkat & Chu et al., 1997 \\
\hline & 293 & Yamit-Hezi and Dikstein, 1998 \\
\hline & Endothelial cells & Stehlik et al., 1998 \\
\hline & EBV infected lymphoblastoid cells & Asso-bonnet et al., 1998 \\
\hline & A549, MCF-7 & Lee et al., 1999 \\
\hline & Glomerular mesangial cells & Sugiyama et al., 1999 \\
\hline & SKOV3.ip1 & Shao et al., 1999 \\
\hline & MIAPaCa-2, Capan- 2 & Kajino et al., 2000 \\
\hline & $\mathrm{CD} 4^{+} \mathrm{T}$ lymphocytes & Khoshnan et al., 2000 \\
\hline & Human pulmonary macrophages & Cross et al., 1999 \\
\hline & Ewing sarcoma cells & Javelaud and Besancon, 2001 \\
\hline & Cardiomyocytes & Bergmann et al., 2001 \\
\hline TNF, IL-1 & Mouse embryos & Li et al., 1999 \\
\hline $\mathrm{TNF} \alpha$, radiation, daunorubicin & HT1080 & Wang et al., 1996 \\
\hline TGF- $\beta$, serum withdrawal, anoikis, TNF $\alpha$ & Mv1Lu and MDCK & Lallemand et al., 2001 \\
\hline SN50 (NF-אB blocker) & T Lymphocytes & Kolenko et al., 1999 \\
\hline Growth factor deprivation & Hematopoietic cells & Besancon et al., 1998 \\
\hline v-Rel & Spleen cells, fibroblasts, C4-1 & You et al., 1997 \\
\hline $\mathrm{v}$-Rel inducers & HeLa cells, spleen cells & Zong et al., 1997 \\
\hline$\gamma$-Radiation & (SKOV3.ipl) cells & Shao et al., 1997 \\
\hline $\mathrm{X}$-ray irradiation & lymphoma cells, Thymocytes & Kawai et al., 1999 \\
\hline TPCK, PDTC (NF-кB blockers) & WEHI 231 & Wu et al., 1996 \\
\hline TRAIL & Renal Cell carcinoma & Oya et al., 2001 \\
\hline Anti-CD95 & Panc TuI & Trauzold et al., 2001 \\
\hline Hyperoxia & A549 & Li et al., 1997 \\
\hline Hyperoxia, TNF $\alpha$ & Lung epithelial cells & Franek et al., 2001 \\
\hline $\mathrm{TNF} \alpha$ and ROI & brain capillary endothelial cells & Ginis et al., 2000 \\
\hline Anisomycin & Myocardial cells & Zechner et al., 1998 \\
\hline Calpain 3 deficiency & myogenic satellite cells & Baghdiguian et al., 1999. \\
\hline Insulin & $\mathrm{CHO}$ overexpressing insulin receptor & Bertrand et al., 1999 \\
\hline TPA and IFN- $\gamma$ & Kerationocytes & Qin et al., 1999 \\
\hline Toxoplasma gondii & T-cells & Caamana et al., 2000 \\
\hline Gas 6 suppression & NIH $3 \mathrm{~T} 3$ & Demarchi et al., 2001 \\
\hline TNF & Endothelial cells & Hofer-Warbinek et al., 2000 \\
\hline NIK suppression & $\mathrm{PC} 12$ & Foehr et al., 2000 \\
\hline Serum depletion, sodium butyrate & GSM 06 & Kanai et al., 2001 \\
\hline
\end{tabular}

MCF-7, human breast carcinoma; Panc TuI, human pancreatic adenocarcinoma; A549, nonsmall cell lung cancer; SKOV3ip1, human ovarian cancer cell line was generated from ascites developed in $n u / n u$ mouse by administering an intraperitoneal injection of SK-OV-3, a human ovarian carcinoma cell line; MIAPaCa-2 and Capan-2, human pancreatic cancer cell lines; HT1080, fibrosarcoma; Mv1Lu and MDCK, epithelial cells; C4-1 and WEHI 231, B cells; PC12, rat adrenal pheochromocytoma; GSM 06, gastric mucosal cell line.

apoptotic genes. The inhibition of NF- $\mathrm{BB}$ nuclear translocation enhances apoptotic killing by cytokines that belong to the TNF superfamily, ionizing radiation, overexpression of oncoproteins, chemotherapeutic agents, cytokines, phorbol esters, hyperoxia, hormones, and micro- organisms (Table 1).

Some earlier studies showed that the oncogene v-rel from the avian retrovirus reticuloendotheliosis virus strain can block apoptosis (for references see Gilmore, 1999) in chickens. Similarily, v-rel rendered chicken B cells resistant to 
Pro-apoptotic $\mathrm{NF}-\kappa \mathrm{B}$ regulated gene products

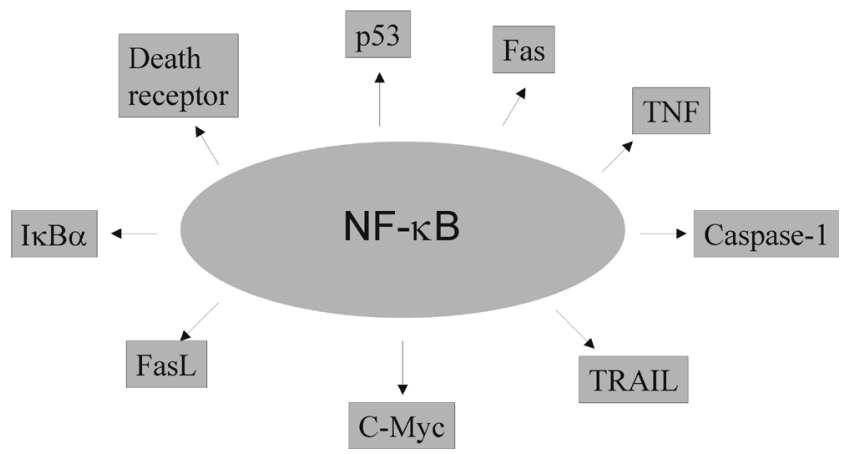

Fig. 2. Positive regulation of apoptosis by the NF- $\kappa B$-regulated gene products.

radiation-induced apoptosis (Neiman et al., 1991). A large number of reports have demonstrated the anti-apoptotic effect of NF-KB in a wide variety of cell types. The protective role of NF- $\mathrm{KB}$ is shown in a large variety of cell types, including the human breast carcinoma (Liu et al., 1996), T cells (Van Antwerp et al., 1996; Chu et al., 1997; Khoshnan et al., 2000), fibroblasts and macrophages (Beg and Baltimore, 1996), endothelial cells (Stehlik et al., 1998), EBV-infected lymphoblastoid cells (Asso-bonnet et al., 1998), non-small lung cancer cells (Lee et al., 1999), glomerular mesangial cells (Sugiyama et al., 1999), human ovarian cancer cells (Shao et al., 1997), human pancreatic cancer cell lines (Kajino et al., 2000), Ewing sarcoma cells (Javelaud and Besancon, 2001), cardiomyocytes (Bergmann et al., 2001), mouse embryos (Li et al., 1999), and HT1080 fibrosarcoma (Wang et al., 1996).

Treatment of RelA-deficient (the transcriptionally active subunit of NF- $\kappa \mathrm{B}$ ) mouse fibroblasts and macrophages with TNF significantly reduced cell viability, whereas RelA ${ }^{+/+}$cells were unaffected. In addition, reintroduction of RelA into RelA $^{-/}$fibroblasts enhanced survival, demonstrating that Rel $\mathrm{A}$ is required for protection from TNF (Beg and Baltimore, 1996). Another report showed that activation of the NF-KB by TNF, ionizing radiation, or daunorubicin protects cells from apoptosis, whereas inhibition of NF- $\mathrm{BB}$ enhanced apoptotic killing by these reagents, but not by apoptotic stimuli that do not activate NF-кB (Wang et al., 1996). Van Antwerp et al. (1996), however, showed that the sensitivity and kinetics of TNF-induced apoptosis are enhanced in a number of cell types that express a dominant-negative I $\mathrm{B} \alpha \alpha$ (an inhibitor of $\mathrm{NF}-\kappa \mathrm{B})$. The continued expression of $\mathrm{v}-\mathrm{Rel}$ is necessary to maintain the viability of transformed lymphoid cells, and enables primary spleen cells to escape apoptosis in culture (Zong et al., 1997).

Liu et al. (1996) used signaling proteins and showed the following: the recruitment of FADD to the TNFR1 complex mediates apoptosis; the recruitment of RIP and TRAF2 mediate NF- $\mathrm{KB}$ activation; and the activation of the latter protects cells against TNF-induced apoptosis. The substoichiometric TFIID subunit TAFII105 is essential for activation of anti-apoptotic genes in response to TNF- $\alpha$, which serves as a transcriptional co-activator for $\mathrm{NF}-\kappa \mathrm{B}$ (Yamit-Hezi and Dikstein , 1998).

The adenovirus E1A protein inhibited the activation of NF$\kappa \mathrm{B}$ and rendered the cells more sensitive to TNF-induced apoptosis. This inhibition was brought about through the

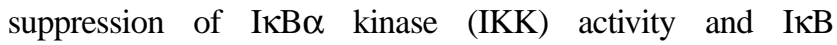
phosphorylation (Shao et al., 1999). NF- $\kappa B$ can attenuate TNF- $\alpha$-induced apoptosis without de novo protein synthesis in the human pancreatic cancer cell lines, MIA PaCa- 2 and Capan-2. TNF- $\alpha$-induced apoptosis was blocked by IL-1 $\beta$, a potent inducer of $\mathrm{NF}-\kappa \mathrm{B}$ activation (Kajino et al., 2000). These findings suggest that de novo protein synthesis is dispensable for anti-apoptotic effects of NF- $\mathrm{BB}$, and support the possibility that NF- $\kappa \mathrm{B}$ exerts its anti-apoptotic action through protein-protein interaction.

The NF- $\kappa \mathrm{B}$ cascade is important in the Bcl-xL expression and for the anti-apoptotic effects of the CD28 receptor in primary human $\mathrm{CD}^{+}$lymphocytes (Khoshnan et al., 2000). HuT-78, a lymphoblastoid T cell line with constitutive NF- $\kappa B$ activity, contains elevated levels of the $\mathrm{Bcl}-\mathrm{xL}$ protein and, similar to the proliferating $\mathrm{CD}^{+} \mathrm{T}$ cells, is resistant to apoptotic stimuli such as anti-Fas and TNF $\alpha$. In contrast, the same stimuli readily induced apoptosis in Jurkat cells without producing any detectable Bcl-xL expression.

The quinone reductase inhibitors dicoumarol and menadione block SAPK/JNK and NF- $\kappa \mathrm{B}$, and thereby potentiate apoptosis (Cross et al.,1999). Javelaud and Besancon demonstrated that the repression of JNK activation by $N F-\kappa B$ is involved in the anti-apoptotic effect of this transcription factor in TNF $\alpha$-treated Ewing sarcoma cells (Javelaud and Besancon, 2001). Also, NF- $\kappa B$ exercises its anti-apoptotic effects through NF- $\mathrm{kB}$-inducing kinases (NIK). NIK induces PC12 cell differentiation and prevents apoptosis (Foehr et al., 2000). Cardiomyocytes utilize the transcription factor NF- $\kappa B$ to activate survival factors in the context of TNF- $\alpha$ stimulation. As locally increased levels of TNF $\alpha$ have been detected in heart failure, NF- $\mathrm{KB}$ activity is essential for cellular homeostasis in the heart (Bergmann et al., 2001).

$\mathrm{NF}-\kappa \mathrm{B}$ is required for TNF-mediated induction of the gene that encoded human c-IAP2. When overexpressed in mammalian cells, c-IAP2 activates NF- $\mathrm{BB}$ and suppresses TNF cytotoxicity. Both of these c-IAP2 activities are blocked in vivo by the co-expression of a dominant form of $\mathrm{I} \kappa \mathrm{B}$ that is resistant to TNF-induced degradation (Chu et al., 1997). Functional coupling of NF- $\mathrm{KB}$ and c-IAP2 during the TNF response may provide a signal amplification loop that promotes cell survival rather than death. The iap genes function to protect the cell from undergoing apoptotic death in response to a variety of stimuli. The iap genes hiap1, hiap 2, and xiap are strongly up-regulated upon treatment of the endothelial cells with the inflammatory cytokines TNF $\alpha$, IL$1 \beta$, and LPS, which in turn leads to the activation of NF- $\kappa B$. 
Table 2. Pro-apoptotic activity of NF- $\kappa \mathrm{B}$

\begin{tabular}{|c|c|c|}
\hline Inducing agent & Cell Type & Reference \\
\hline $\mathrm{TNF} \alpha$ & Myeloid lukemic cell lines & Hu et al., 1999 \\
\hline Fas/TNF $\alpha$ & CEM-C7 & Packham et al., 1997 \\
\hline TNF $\alpha ;$ HTLV-1 Tax/TNF $\alpha$ & Osteoblast cell line & Kitajima et al., 1996 \\
\hline ROI & Astrocytes & Takuma et al., 1999 \\
\hline Oxidative stress & Aortic endothelial cells & Aoki et al., 2001 \\
\hline \multirow[t]{2}{*}{ Hydrogen peroxide } & Oligodendrocytes & Vollgraf et al., 1999 \\
\hline & Jurkat/CEM C7 & Dumont et al., 1999 \\
\hline Etoposide & HL-60 and thymocytes & Bessho et al., 1994 \\
\hline Kainic acid & Rat striatum & Nakai et al., 2000 \\
\hline Focal cerebral ischemia & Neurons (Mice Ischemic model) & Schneider et al., 1999 \\
\hline$\alpha-\mathrm{CD} 3$ & Thymocytes from mIкB- $\alpha$ mice & Hettmann et al., 1999 \\
\hline PKR & BSC-40, 3T3 & Gil et al., 1999 \\
\hline Constitutive enhanced by etoposide & Immature Rat thymocytes & Slater et al., 1995 \\
\hline Aspirin & Colon cancer cells & Stark et al., 2001 \\
\hline UV light & Human melanoma & Ivanov et al., 2000 \\
\hline Helicobacter pylori & Gastric epithelial cells & Gupta et al., 2001 \\
\hline Sindbis-virus induction & AT-3 & Lin et al., 1995; Lin et al., 1998 \\
\hline Adenovirus & Hepatocytes & Kuhnel et al., 2000 \\
\hline
\end{tabular}

CEM-C7, human T cells; Jurkat, T cells; HL-60, human promyelocytic lukemia; BSC-40, African green monkey kidney cells; AT-3, prostrate carcinoma cell line; PKR,double stranded-RNA-dependent protein pinase.

This suggests that xiap represents one of the NF- $\mathrm{BB}$-regulated genes that counteracts the apoptotic signals that are elicited by $\mathrm{TNF} \alpha$, thereby preventing endothelial cells from undergoing apoptosis during inflammation (Stehlik et al., 1998).

Treatment of the WEH1 231 cells with N-tosyl-Lphenylalanine chloromethyl ketone, a protease inhibitor that prevents degradation of $\mathrm{I} \kappa \mathrm{B} \alpha$, or with low doses of pyrrolidine dithiocarbamate, selectively inhibited NF- $\kappa B$ activation and induced apoptosis (Wu et al., 1996). Similarly, the microinjection of the WEHI 231 cells with either the I $\mathrm{B} \alpha$-GST protein or a c-Rel affinity-purified antibody induced apoptosis (Wu et al., 1996).

Arlt et al. have shown that under certain conditions the resistance of pancreatic carcinoma cells to chemotherapy is due to their constitutive NF- $\kappa B$ rather than the transient induction of $\mathrm{NF}-\kappa \mathrm{B}$ by some anti-cancer drugs. (Arlt et al., 2001). Exposure of normal keratinocytes to IFN- $\gamma$ plus TPA produced a synergistic activation of NF- $\mathrm{KB}$. They acquired a resistance to UV-light-induced apoptosis that was dependent on $\mathrm{NF}-\kappa \mathrm{B}$, because the expression of a dominant negative form of $\mathrm{I} \kappa \mathrm{B} \alpha$ overcame the resistance (Qin et al., 1999). There is enough evidence to suggest that activation and proper regulation of NF- $\kappa B$ is essential for the acquisition of an apoptotic-resistant phenotype for epidermal-derived keratinocytes. Kolenko et al. (1999) demonstrated that the inhibition of NF- $\mathrm{KB}$ activity by cell permeable SN50 peptide in human $\mathrm{T}$ lymphocytes induces caspase-dependent apoptosis. Kawai et al. (1999) have shown that p53 is involved in NF- $\kappa \mathrm{B}$ inactivation, and is required for X-ray-induced apoptosis in thymic lymphoma cells and normal thymocytes.
Oxidative stress induces apoptosis in human aortic endothelial cells through the down-regulation of bcl-2, translocation of bax, and up-regulation of p53, probably through NF- $\kappa \mathrm{B}$ activation. Oxidative stress may play an important role in endothelial apoptosis that is mediated by hypoxia, through the activation of NF-KB (Aoki et al., 2001). $\mathrm{NF}-\kappa \mathrm{B}$ is a redox-sensitive transcription factor that is activated by oxidative insult. Also, NF- $\kappa \mathrm{B}$ activation can protect cells from apoptosis. When human alveolar epithelial (A549) cells were exposed to hyperoxia, NF- $\kappa \mathrm{B}$ was activated and within minutes was translocated to the nucleus (Li et al., 1997). Reactive oxygen species could act synergistically with TNF $\alpha$, causing cytotoxicity via inhibition of a cytoprotective branch of TNFQ signaling pathways that starts with NF- $\kappa B$ activation. Ginis et al. demonstrated that $\mathrm{H}_{2} \mathrm{O}_{2}$ inhibited TNF $\alpha$-induced accumulation of p65 in the nucleus, although it had no effect on the degradation of IKB in the cytoplasm (Ginis et al., 2000).

Adenovirus protein E1B blocks TNF-induced apoptosis, whereas E1A enhances TNF-induced apoptosis through unknown mechanisms. Recent evidence indicates that the effect of these proteins is mediated through modulation of NF$\kappa B$ activation (Shao et al., 1997).

The growth arrest-specific 6 gene product (Gas6) is a growth and survival factor that is related to protein S. Gas6 induces a rapid and transient increase in nuclear NF- $\kappa B$ binding activity that is coupled to transcription activation. This plays a central role in promoting survival in NIH 3T3 cells (Demarchi et al., 2001). MKK6 activates myocardial cell NF$\mathrm{\kappa B}$ and inhibits apoptosis in a p38 mitogen-activated protein 
kinase dependent manner (Zechner et al., 1998). Limb girdle muscular dystrophy type $2 \mathrm{~A}$ results in a decreased production of calpain 3. Calpain 3 is responsible for the $\mathrm{I} \kappa \mathrm{B} \alpha$ turnover. Over expression of $\mathrm{I} \kappa \mathrm{B} \alpha$ results in the sequestration of NF$\kappa \mathrm{B}$ outside the nucleus. Myonuclear apoptosis was caused by the down-regulation of NF- $\mathrm{BB}$ (Baghdiguian et al., 1999).

The stimulation of the CD95- and TRAIL-resistant human pancreatic adenocarcinoma cell line, Panc TuI, with an agonistic anti-CD95 antibody or TRAIL activates protein kinase $\mathrm{C}$ and NF- $\mathrm{KB}$. The activation of PKC operates directly in a death receptor dependent manner in PancTuI cells and pancreatic tumor cells, protecting them from anti-CD95 and TRAIL-mediated apoptosis by preventing the loss of DeltaPsim and cytochrome c release, as well as by the induction of NF- $\mathrm{KB}$ (Trauzold et al., 2001). Pharmacologic or molecular inhibition of the NF- $\mathrm{BB}$ pathway blocked cell survival in MCF-7 APO+ cells, while only molecular inhibition induced cytotoxicity in the APO- cells (Weldon et al., 2001). TGF- $\alpha$ protected gastric mucosal cells against apoptosis that is induced by serum depletion or sodium butyrate in a dose-dependent manner. This anti-apoptotic effect of TGF- $\alpha$ was blocked by pre-treatment with reagents that can potentially inhibit NF- $\mathrm{KB}$ activation. This suggests that TGF- $\alpha$ plays an antiapoptotic role in gastric mucosal cells via the NF-אB-dependent pathway (Kanai et al., 2001).

Mice deficient in the NF- $\mathrm{\kappa B}_{2}$ gene were challenged with the intracellular parasite Toxoplasma gondii. During the chronic phase of the infection, susceptibility of NF- $\kappa B$ knockout mice to toxoplasmic encephalitis was associated with a reduced capacity of their splenocytes to produce IFN- $\gamma$ that is associated with a loss of $\mathrm{CD}^{+}{ }^{+}$and $\mathrm{CD} 8^{+} \mathrm{T}$ cells. This loss of $\mathrm{T}$ cells correlated with the increased levels of apoptosis and with the elevated expression of the pro-apoptotic molecule Fas by T-cells from infected NF- $\kappa B$ knockout mice. This suggests a role of $N F-\kappa B$ in maintenance of $T$ cell responses that are required for long-term resistance to Toxoplasma gondii (Caamano et al., 2000).

\section{How NF-kB suppresses apoptosis}

Although it is clear that NF- $\mathrm{BB}$ activation plays a role in suppressing TNF-induced apoptosis, just how is only now beginning to emerge. Several genes that may play a role in blocking apoptosis, and whose expression is regulated by NF$\kappa \mathrm{B}$, have been identified. These include cellular inhibitors of apoptosis (cIAP)-1 and cIAP-2, TRAF-1, and TRAF-2 (Chu et al., 1997; Stehlik et al., 1998; Wang et al., 1998). cIAP-1, cIAP-2, and TRAF-1 are known to bind to TRAF-2, and TRAF-2 is required for NF- $\mathrm{BB}$ activation. Thus, how these proteins block apoptosis is unclear. Other reports show that TNF induces manganous superoxide dismutase (SOD), whose expression is also regulated by NF- $\mathrm{kB}$. The overexpression of SOD induces resistance to TNF-induced apoptosis (Manna et al., 1998). Also, the altered SOD expression in HeLa cells after low dose gamma-irradiation is responsible for NF- $\mathrm{kB}$ - mediated cisplatin resistance (Eichholtz-Wirth et al., 2000). Insulin manifests its antiapoptotic signaling though the activation of NF-KB-dependent survival genes that encode TRAF-2 and SOD (Bertrand et al., 1999). The TNF-inducible zinc finger protein A20 (Opipari et al., 1992) is regulated by NF-KB (Krikos et al., 1992), and the role of this protein in the induction of resistance to TNF-induced apoptosis has been demonstrated (Opipari et al., 1992). The expression of a protein that is critical in the regulation of the cell cycle, cyclin $\mathrm{D} 1$, is also regulated by NF- $\mathrm{KB}$. This activity may contribute to the cell growth and differentiation function assigned to NFкB (Guttridge et al., 1999; Hinz et al., 1999).

The pro-survival Bcl-2 homolog Bfl-1/A1 is another gene whose transcription is regulated by NF- $\kappa \mathrm{B}$ and blocks TNFinduced apoptosis (Wang, 1999; Zong et al., 1999). There are other studies that show that Bcl-2 activates NF- $\kappa \mathrm{B}$ through the degradation of the inhibitor $\mathrm{I} \kappa \mathrm{B} \alpha$ (de Moissac et al., 1998). Crawford et al. demonstrated that Bcl-2 over-expression protects photooxidative stress-induced apoptosis of photoreceptor cells through NF- $\kappa \mathrm{B}$ preservation. The Ras/PI$3 \mathrm{~K} / \mathrm{Akt}$ pathway plays a critical role in cell survival. It now appears that this pathway is also linked to the activation of IKK, the kinase needed for IkB $\alpha$ phosphorylation and NF- $\kappa B$ activation. Akt may also play a cytoprotective role through activation of NF- $\mathrm{KB}$ (Romashkova and Makarov, 1999, Yang et al., 2001). A NF- $\kappa \mathrm{B}$-independent cytoprotective pathway has also been described. The NF- $\mathrm{KB}$ activation that is induced by the over-expression of TRAF2 was found to be insufficient to protect cells from apoptosis that is induced by TNF and cycloheximide together. This indicates an essential role for additional components in the cytoprotective response (Natoli et al., 1998).

While NF- $\kappa B$ activation blocks apoptosis, it seems that the activation of apoptosis also blocks NF- $\mathrm{BB}$ activation, suggesting a feedback loop. For instance, endothelial cells undergo apoptosis when deprived of growth factors. The surviving viable cells exhibit increased activity of NF- $\kappa B$, whereas apoptotic cells show caspase-mediated cleavage of the NF- $\kappa$ B p65/RelA subunit. This results in the loss of carboxy-terminal transactivation domains and a transcriptionally inactive p65 molecule, which itself acts as a dominant-negative inhibitor of NF- $\kappa \mathrm{B}$, promoting apoptosis. In contrast, an uncleavable caspase-resistant p65 protects the cells from apoptosis. The generation of a dominant-negative fragment of p65 during apoptosis may be an efficient proapoptotic feedback mechanism between caspase activation and NF- $\mathrm{KB}$ inactivation (Levkau et al., 1999). Similarly, apoptosis has been shown to promote a caspase-induced amino-terminal truncation of $\mathrm{I} \kappa \mathrm{B} \alpha$ that functions as a stable inhibitor of NF- $\kappa B$ (Reuther and Baldwin, 1999), thus further enhancing apoptosis. Fas (another member of the TNF receptor family) was also found to induce caspase 3-mediated

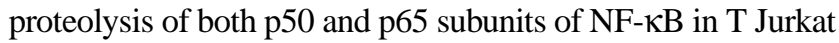
cells, thus sensitizing the cells to apoptosis (Ravi et al., 1998). 


\section{Pro-apoptotic activity of NF-kB}

The decision of life or death in response to an inducing signal within a cell is dependent upon a delicate balance of positive and negative influences. While there are several reports that NF- $\mathrm{KB}$ activation protects cells from undergoing apoptosis that is induced by TNF or chemotherapeutic agents, there are also reports that suggest that NF- $\mathrm{KB}$ activation mediates apoptosis in response to a variety of inducers in a number of cell types. For instance, in murine clonal osteoblasts, the NF$\kappa \mathrm{B}$ activation mediated the TNF-induced apoptosis (Kitajima et al., 1996). The suppression of the growth of $\mathrm{CD} 34^{+}$myeloid cells by TNF also correlated with the NF- $\mathrm{KB}$ activation (Hu et al., 1999). Apart from this, Fas activates NF-кB and induces apoptosis in T-cell lines by signaling pathways that are distinct from those induced by TNFa (Packham et al., 1997). Human melanoma cells are protected against UV-induced apoptosis through the down-regulation of NF-KB activity and Fas expression (Ivanov and Ronai, 2000). Oxidative stress induced apoptosis in human aortic endothelial cells through the downregulation of bcl-2, translocation of bax, and up-regulation of p53 that probably takes place through NF- $\mathrm{KB}$ activation. Oxidative stress may play an important role in endothelial apoptosis that is mediated by hypoxia through the activation of NF- $\mathrm{kB}$ (Aoki et al., 2001). The activation of NF- $\mathrm{kB}$ is required for apoptosis, as has also been shown for other inducers such as $\mathrm{H}_{2} \mathrm{O}_{2}$ (Dumont et al., 1999; Vollgraf et al., 1999). Similarly, $\mathrm{H}_{2} \mathrm{O}_{2}$-induced apoptosis was not suppressed by hyperoxia-induced NF- $\kappa \mathrm{B}$ activation ( $\mathrm{Li}$ et al., 1997). In pancreatic islets, A20 inhibited both apoptosis and NF- $\mathrm{KB}$ activation that is induced by cytokines. This suggests that NFKB may actually mediate apoptosis (Grey et al., 1999). Apoptosis in HL-60 cells that is induced by chemotherapeutic agents, such as etoposide or 1-beta-Darabinofuranosylcytosine, was also found to require NF-kB activation since the suppression of NF- $\mathrm{KB}$ by PDTC also blocked apoptosis (Bessho et al., 1994).

Recently, Stark et al. demonstrated that aspirin induces cell death by an active apoptotic process that involves nuclear translocation of NF- $\mathrm{KB}$ preceding cell death (Stark et al., 2001). Helicobacter pylori induces NF-кB-mediated apoptosis in chronic gastritis (Gupta et al., 2001). The apoptosis that is induced by alphavirus was also found to require the activation of NF-KB (Lin et al., 1995), since thiol agents and Bcl-2 blocked both activities. During adenoviral infection, NF- $\mathrm{kB}$ mediates apoptosis through transcriptional activation of Fas (CD95) (Kuhnel et al., 2000). Apoptosis in $\mathrm{Ca}^{++}$reperfusion injury of cultured astrocytes was also found to be mediated through NF-KB activation (Takuma et al., 1999). The cell death-promoting role of NF- $\mathrm{KB}$ has also been demonstrated in focal cerebral malaria (Schneider et al., 1999), as it has for the induction of apoptosis by doublestranded-RNA-dependent protein-kinase (PKR) (Gil et al., 1999). Lin et al. (1998) showed that NF-KB can be proapoptotic or antiapoptotic, depending on the timing of the modulating NF- $\kappa B$ activity relative to the death stimulus. How NF- $\mathrm{kB}$ may mediate apoptosis is unclear, but the role of p53 and c-myc induction through NF- $\mathrm{KB}$ has been demonstrated (Nakai et al., 2000). In addition, NF-KB is required for the anti-CD3-mediated apoptosis of double-positive thymocytes through a pathway that involves the regulation of the antiapoptotic gene bcl-XL ( Hettmann et al., 1999). c-myc has also been implicated in the survival of certain cells such as hepatocytes (Bellas and Sonenshein, 1999). These observations suggest that NF- $\mathrm{KB}$ activation not only negatively, but also positively regulates apoptosis. This idea has been further strengthened by studies on NMRI mice, Wistar rats, and WI-38 fibroblasts where aging induced a strong and consistent increase in the nuclear binding activity of NF-KB (Helenius et al., 1996).

\section{Evidence that apoptosis is unaffected by NF-kappaB}

There are increasing reports that NF- $\mathrm{KB}$ activation plays little or no role in apoptosis. For instance, Cai et al. showed that the overexpression of I $\mathrm{I} B \alpha$, an inhibitor of NF- $\mathrm{\kappa B}$, in the human breast carcinoma MCF7 cells inhibits NF- $\mathrm{kB}$ activation, but not TNF-induced apoptosis. Similarly, in endothelial cells, A20 inhibited NF-KB activation without enhancing TNFinduced apoptosis (Ferran et al., 1998). LPS- and IL-1induced prolongation in the survival of endothelial cells did not require NF-KB activation (Zen et al., 1999). The pro- and anti-apoptotic role of NF-kB appears to be determined more by the nature of the death stimulus than by the origin of the tissue (Kuhnel et al., 2000). Bone morphogenetic protein (BMP)-2 and -4 inhibited the TNF-mediated apoptosis by inhibiting caspase- 8 activation in $\mathrm{C} 2 \mathrm{C} 12$ cells, a pluripotent mesenchymal cell line that has the potential to differentiate into osteoblasts, depending on BMP stimulation. The BMP/ Smad signaling pathway can inhibit TNF-mediated apoptosis independently of the pro-survival activity of NF- $\mathrm{kB}$. This suggests that BMPs not only stimulate osteoblast differentiation, but also promote cell survival during the induction of bone formation. This offers new insights into the biological functions of BMPs (Chen et al., 2001). There are proteins that associate with cytokine receptors, such as SODD (for silencer of death domain) (Jiang et al., 1999), sentris (Okura et al., 1996), and c-FLIP (Scaffidi et al., 1999). These can also negatively regulate apoptosis, again independently of NF- $\mathrm{KB}$.

The redox-sensitive transcription factor Ref- 1 plays a critical role in the survival of endothelial cells in response to hypoxia and cytokines, including TNF $\alpha$. The up-regulation of Ref-1 promotes endothelial cell survival in response to hypoxia and TNF through NF- $\mathrm{KB}$ independent and NF- $\mathrm{\kappa B}-$ dependent signaling cascades (Hall et al., 2001). The human non-small-cell lung carcinoma apoptosis induced by topoisomerase poisons, e.g. Etoposide, is not mediated by NF$\kappa \mathrm{B}$, but can be manipulated by proteasome inhibitors (Tabata 
et al., 2001). Why NF-KB plays a role in apoptosis that is induced by some agents and not others is unclear, but suggests that the apoptotic pathway varies from one inducer to another, and also perhaps from one cell type to another.

\section{Conclusion}

From this review, it is clear that apoptosis is regulated by mitochondria-dependent and -independent pathways that involve a series of proteins that pre-exist in the cells. Most of the agents that induce apoptosis also activate NF- $\mathrm{BB}$, and the latter suppresses apoptosis in most cases. While it may appear paradoxical that the same agent could perform both functions, in reality it is not. The same stress that induces cells to die also provokes a self-defense response in the cell. How NF- $\mathrm{KB}$ plays an antiapoptitic role in some cells, pro-apoptotic in others, and no role in some, requires further understanding. It is possible that the activation of NF- $\mathrm{KB}$ alone is insufficient to regulate apoptosis, and that other transcription factors are

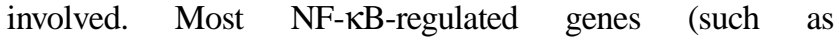
cyclooxygenase-2) play a critical role in inflammation, suggesting that inflammation can also negatively regulate apoptosis. Overall, this review describes our current understanding of the mechanism of the regulation of apoptosis, and the future direction of the research.

\section{References}

Adams, J. M. and Cory, S. (1998) The Bcl-2 protein family: arbiters of cell survival. Science 281, 1322-1326.

Aggarwal, B. B. and Vilcek, J. (1992) Tumor Necrosis Factor: Structure, Function and Mechanism of Action, Marcel Dekker, New York.

Antoku, K., Liu, Z. and Johnson, D. E. (1997) Inhibition of caspase proteases by $\mathrm{CrmA}$ enhances the resistance of human leukemic cells to multiple chemotherapeutic agents. Leukemia 11, 1665-1672.

Aoki, M., Nata, T., Morishita, R., Matsushita, H., Nakagami, H., Yamamoto, K. Yamazaki, K., Nakabayashi, M., Ogihara, T. and Kaneda, Y. (2001) Endothelial apoptosis induced by oxidative stress through activation of NF-kappaB: antiapoptotic effect of antioxidant agents on endothelial cells. Hypertension 38, 48-55.

Arends, M. J. and Wyllie, A. H. (1991) Apoptosis: mechanisms and roles in pathology. Int. Rev. Exp. Pathol. 32, 223-254

Arlt, A., Grobe, O., Sieke, A., Kruse, M. L., Folsch, U. R., Schmidt, W. E. and Schafer, H. (2001) Expression of the NFkappa B target gene IEX-1 (p22/PRG1) does not prevent cell death but instead triggers apoptosis in Hela cells. Oncogene 20, 69-76.

Arlt, A., Vorndamm, J., Breitenbroich, M., Folsch, U. R., Kalthoff, H., Schmidt, W. E. and Schafer, H. (2001) Inhibition of NFkappaB sensitizes human pancreatic carcinoma cells to apoptosis induced by etoposide (VP16) or doxorubicin. Oncogene 20, 859-868.

Ashkenazi, A. and Dixit, V. M. (1998) Death receptors: signaling and modulation. Science 281, 1305-1308.

Asso-Bonnet, M., Feuillard, J., Ferreira ,V., Bissieres, P., Tarantino,
N., Korner, M. and Raphael, M. (1998) Relationship between IkappaBalpha constitutive expression, TNFalpha synthesis, and apoptosis in EBV-infected lymphoblastoid cells. Oncogene 24, 1607-1615.

Baghdiguian, S., Martin, M., Richard, I., Pons, F., Astier, C., Bourg, N., Hay, R. T., Chemaly, R., Halaby, G., Loiselet , J., Anderson, L. V., Lopez de Munain, A., Fardeau, M., Mangeat, P., Beckmann, J. S. and Lefranc, G. (1999) Calpain 3 deficiency is associated with myonuclear apoptosis and profound perturbation of the IkappaB alpha/NF-kappaB pathway in limb-girdle muscular dystrophy type 2A. Nat Med. 5, 503-511.

Beg, A. A. and Baldwin, A. S. ( 1993) The IKB proteins: Multifunctional regulators of Rel/ NF- $\mathrm{KB}$ trancription factors. Genes Dev. 7, 2064-2070.

Beg, A. A. and Baltimore, D. (1996). An essential role for NFkappaB in preventing TNF-alpha-induced cell death. Science 274, 782-784.

Bellas, R. E. and Sonenshein G. E. (1999) Nuclear factor kappaB cooperates with $\mathrm{c}-\mathrm{Myc}$ in promoting murine hepatocyte survival in a manner independent of p53 tumor suppressor function. Cell Growth \& Differ. 10, 287-294.

Bergmann, M. W., Loser, P., Dietz, R. and Harsdorf , R. (2001) Effect of NF- kappa B Inhibition on TNF-alpha-induced Apoptosis and Downstream Pathways in Cardiomyocytes. $J$ Mol. Cell Cardiol. 33, 1223-1232.

Bertrand, F., Desbois-Mouthon, C., Cadoret, A., Prunier, C., Robin, H., Capeau, J., Atfi, A. and Cherqui, G. (1999). Insulin antiapoptotic signaling involves insulin activation of the nuclear factor kappaB-dependent survival genes encoding tumor necrosis factor receptor-associated factor 2 and manganesesuperoxide dismutase. J. Biol. Chem. 274, 30596-30602.

Besancon, F., Atfi. A., Gespach, C., Cayre, Y. E. and Bourgeade, M. F. (1998) Evidence for a role of NF-kappaB in the survival of hematopoietic cells mediated by interleukin 3 and the oncogenic TEL/platelet-derived growth factor receptor beta fusion protein. Proc. Natl. Acad. Sci. USA 95, 8081-8086.

Bessho, R., Matsubara, K., Kubota, M., Kuwakado, K., Hirota, H., Wakazono, Y., Lin, Y. W., Okuda, A., Kawai, M., Nishikomori, R. and Heike, T. (1994) Pyrrolidine dithiocarbamate, a potent inhibitor of nuclear factor kappa B (NF-kappa B) activation, prevents apoptosis in human promyelocytic leukemia HL-60 cells and thymocytes. Biochem. Pharmacol. 48, 1883-1889.

Beyaert, R., Heyninck, K. and Van Huffel, S. (2000) A20 and A20-binding proteins as cellular inhibitors of nuclear factorkappa B-dependent gene expression and apoptosis. Biochem. Pharmacol. 60, 1143-1151.

Brancolini, C., Benedetti, M. and Schneider, C. (1995) Microfilament reorganization during apoptosis: the role of Gas2, a possible substrate for ICE-like proteases. EMBO J. 14, 5179-5190.

Caamano, J., Tato, C., Cai, G., Villegas, E. N., Speirs, K., Craig, L., Alexander, J. and Hunter, C. A. (2000) Identification of a role for NF-kappa B2 in the regulation of apoptosis and in maintenance of $\mathrm{T}$ cell-mediated immunity to Toxoplasma gondii. J. Immunol. 165, 5720-5728.

Cai, Z., Korner, M., Tarantino, N. and Chouaib, S. (1997) IkappaB alpha overexpression in human breast carcinoma MCF7 cells inhibits nuclear factor-kappaB activation but not tumor necrosis factor-alpha-induced apoptosis. J. Biol. Chem. 272, 96-101. 
Casciola-Rosen. L., Nicholson, D. W., Chong, T., Rowan, K. R., Thornberry, N. A., Miller, D. K. and Rosen, A. (1996) Apopain/CPP32 cleaves proteins that are essential for cellular repair: a fundamental principle of apoptotic death. J. Exp. Med. 183, 1957-1964.

Cerretti, D. P., Kozlosky, C. J., Mosley, B., Nelson, N., Van Ness, K., Greenstreet, T. A., March, C. J., Kronheim, S. R., Druck, T. and Cannizzaro, L. A. (1992) Molecular cloning of the interleukin-1 beta converting enzyme. Science 256, 97-100.

Chen, F. E. and Ghosh, G. (1999) Regulation of DNA binding by Rel/NF-kappaB transcription factors: structural views. Oncogene 18, 6845-6852.

Chen, S., Guttridge, D., Tang, E., Shi, S., Guan, K. and Wang, C. Y. (2001) Suppression of tumor necrosis factor-mediated apoptosis by NF-KB-independent BMP/Smad signaling. J. Biol. Chem. 276, 39259-39263.

Chinnaiyan, A. M. and Dixit, V. M. (1996) The cell-death machine. Curr Biol. 6, 555-562.

Chu, Z. L., McKinsey, T. A., Liu, L., Gentry, J. J., Malim, M. H., and Ballard, D. W. ( 1997) Suppression of tumor necrosis factor-induced cell death by inhibitor of apoptosis c-IAP2 is under NF-kappaB control. Proc. Natl. Acad. Sci. USA 94, 10057-10062.

Clarke, P. G. and Clarke, S. (1995) Historic apoptosis. Nature. 16, 378(6554): 230.

Cohen, J. J. (1993) Apoptosis. Immunol. Today 14, 126-130.

Cohen, G. M. (1997) Caspases: the executioners of apoptosis. Biochem. J. 326, 1-16.

Crawford, M. J., Krishnamoorthy, R. R., Rudick, V.L., Collier, R. J., Kapin, M., Aggarwal, B. B., Al-Ubaidi, M. R. and Agarwal, N. (2001) Bcl-2 overexpression protects photooxidative stressinduced apoptosis of photoreceptor cells via NF-kappaB preservation. Biochem. Biophys. Res. Commun. 281, 13041312.

Cross, J. V., Deak, J. C., Rich, E. A., Qian, Y., Lewis, M., Parrott, L. A., Mochida, K., Gustafson, D., Vande Pol, S. and Templeton, D. J. (1999) Quinone reductase inhibitors block SAPK/JNK and NFkappaB pathways and potentiate apoptosis. J. Biol. Chem. 274, 31150-31154.

Darmon, A. J., Nicholson, D. W. and Bleackley, R. C. (1995) Activation of the apoptotic protease CPP32 by cytotoxic T-cellderived granzyme B. Nature 377, 446-448.

Darnay, B. G. and Aggarwal, B. B. (1999) Signal transduction by TNF and TNF-related Ligands and Their receptors. Ann. Rheumatic Diseases 58, S0-S11.

de Moissac, D., Mustapha, S., Greenberg, A. H. and Kirshenbaum, L. A. (1998) Bcl-2 activates the transcription factor NF-kappaB through the degradation of the cytoplasmic inhibitor IkappaBalpha. J. Biol. Chem. 273, 23946-23951.

Demarchi, F., Verardo, R., Varnum, B., Brancolini, C. and Schneider, C. (2001) Gas6 anti-apoptotic signaling requires NFkappa B activation. J. Biol. Chem. 276, 31738-31744.

Dumont, A., Hehner, S. P., Hofmann, T. G., Ueffing, M., Droge, W. and Schmitz, M. L. (1999) Hydrogen peroxide-induced apoptosis is CD95-independent, requires the release of mitochondria-derived reactive oxygen species and the activation of NF-kappaB. Oncogene 18, 747-757.

Eichholtz-Wirth, H. and Sagan, D. (2000) IkappaB/NF-kappaB mediated cisplatin resistance in HeLa cells after low-dose gamma-irradiation is associated with altered SODD expression.
Apoptosis 5, 255-263.

Enari, M., Sakahira, H., Yokoyama, H., Okawa, K., Iwamatsu, A. and Nagata, S. A. (1998) Caspase-activated DNase that degrades DNA during apoptosis, and its inhibitor ICAD. Nature 391, 43-50.

Ferran, C., Stroka, D. M., Badrichani, A. Z., Cooper, J. T., Wrighton, C. J., Soares, M., Grey, S. T. and Bach, F. H. (1998) A20 inhibits NF-kappaB activation in endothelial cells without sensitizing to tumor necrosis factor-mediated apoptosis. Blood 91, 2249-2258.

Foehr, E. D., Lin, X., O'Mahony, A., Geleziunas, R., Bradshaw, R. A. and Greene, W. C. (2000) NF-kappa B signaling promotes both cell survival and neurite process formation in nerve growth factor-stimulated PC12 cells. J. Neurosci. 20, 75567563.

Franek, W. R., Horowitz, S., Stansberry, L., Kazzaz, J. A., Koo, H. C., Li, Y., Arita, Y., Davis, J. M., Mantell, A. S., Scott, W. and Mantell, L. L. (2001) Hyperoxia inhibits oxidant-induced apoptosis in lung epithelial cells. J. Biol. Chem. 276, 569-575.

Ghosh, S., May, M. J. and Kopp, E. B. (1998) NF-кB and Rel proteins: Evolutionary conserved mediators of immune responses. Annu. Rev. Immunol. 16, 225-260.

Gil, J., Alcami, J. and Esteban, M. (1999) Induction of apoptosis by double-stranded RNA-dependent protein kinase (PKR) involves the alpha subunit of eukaryotic translation initiation factor 2 and NF-kappaB. Mol. Cell. Biol. 19, 4653-4663.

Gilmore, T. D., Koedood, M., Piffat, K.A. and White, D. W. (1996) Rel/NF-kappaB/lkappaB proteins and cancer. Oncogene 13, 1367-1378.

Gilmore, T. D. (1999) Multiple mutations contribute to the oncogenicity of the retroviral oncoprotein v-Rel. Oncogene. 18, 6925-6937.

Ginis, I., Hallenbeck, J. M., Liu, J., Spatz, M., Jaiswal, R. and Shohami, E. (2000) Tumor necrosis factor and reactive oxygen species cooperative cytotoxicity is mediated via inhibition of NF-kappaB. Mol. Med. 6, 1028-1041.

Green, D. R. and Reed, J. C. (1998) Mitochondria and apoptosis. Science 281, 1309-1312.

Green, D. R. (2000) Apoptotic pathways: paper wraps stone blunts scissors. Cell 102, 1-4.

Grey, S. T., Arvelo, M. B., Hasenkamp, W., Bach, F. H. and Ferran, C. (1999) A20 inhibits cytokine-induced apoptosis and nuclear factor kappaB-dependent gene activation in islets. $J$. Exp. Med. 190, 1135-1146.

Gross, A., McDonnell, J. M. and Korsmeyer, S. J. (1999) BCL-2 family members and the mitochondria in apoptosis. Genes Dev. 13, 1899-911.

Gupta, R. A., Polk, D. B., Krishna, U., Israel, D. A., Yan, F., DuBois, R. N. and Peek R. M. Jr. (2001) Activation of peroxisome proliferator-activated receptor gamma suppresses nuclear factor kappa B-mediated apoptosis induced by Helicobacter pylori in gastric epithelial cells. J. Biol. Chem. 276, 31059-31066.

Guttridge, D. C., Albanese, C., Reuther, J. Y., Pestell, R. G. and Baldwin, A. S. Jr. (1999) NF-kappaB controls cell growth and differentiation through transcriptional regulation of cyclin D1. Mol. Cell. Biol. 19, 5785-5799.

Hall, J. L., Wang, X., Van Adamson, Zhao, Y. and Gibbons, G. H. (2001) Overexpression of Ref-1 inhibits hypoxia and tumor necrosis factor-induced endothelial cell apoptosis through 
nuclear factor-kappaB-independent and -dependent pathways. Circ. Res. 88, 1247-1253.

Haridas, V., Shrivastava, A., Su, J., Yu, G-L., Ni, J., Liu, D., Chen, S-F., Ni Y., Ruben, S. M., Gentz, R. and Aggarwal, B. B. (1999) VEGI, a New Member of the TNF Family Activates Nuclear Factor- $\mathrm{KB}$ and c-Jun N-Terminal Kinase and Modulates Cell Growth. Oncogene 18, 6496-6504.

Helenius, M., Hanninen, M., Lehtinen, S. K. and Salminen, A. (1996) Changes associated with aging and replicative senescence in the regulation of transcription factor nuclear factor-kappa B. Biochem. J. 318, 603-608.

Herrmann, J. L., Beham, A. W., Sarkiss, M., Chiao, P. J., Rands, M. T., Bruckheimer, E. M., Brisbay, S. and McDonnell, T. J. (1997) Bcl-2 suppresses apoptosis resulting from disruption of the NF-kappa B survival pathway. Exp. Cell Res. 237, 101-109.

Hettmann, T., DiDonato, J., Karin, M. and Leiden, J. M. (1996) An essential role for nuclear factor kappaB in promoting double positive thymocyte apoptosis. J. Exp. Med. 189, 145158.

Hinz, M., Krappmann, D., Eichten, A., Heder, A., Scheidereit, C. and Strauss, M. (1999) NF-kappaB function in growth control: regulation of cyclin D1 expression and G0/G1-to-S-phase transition. Mol. \& Cell. Biol. 19, 2690-2698.

Hofer-Warbinek, R., Schmid, J. A., Stehlik, C., Binder, B. R., Lipp, J. and de Martin R. (2000) Activation of NF-kappa B by XIAP, the $\mathrm{X}$ chromosome-linked inhibitor of apoptosis, in endothelial cells involves TAK1. J. Biol. Chem. 275, 2206422068.

Hu, X., Tang, M., Fisher, A. B., Olashaw, N. and Zuckerman, K. S. (1999) TNF-alpha-induced growth suppression of CD34+ myeloid leukemic cell lines signals through TNF receptor type I and is associated with NF-kappa B activation. J. Immunol. 163, 3106-3115.

Ivanov, V. N. and Ronai, Z. (2000) p38 protects human melanoma cells from UV-induced apoptosis through down-regulation of NF-kappaB activity and Fas expression. Oncogene 19, 30033012.

Ivanov, V. N. Fodstad, O. and Ronai, Z. (2001) Expression of zinc finger-deleted TRAF2 sensitizes metastatic melanoma cells to apoptosis via up-regulation of $\mathrm{p} 38$, TNFalpha and suppression of NF-kappaB activities. Oncogene 20, 2243-2253.

Jaattela, M. (1999) Escaping cell death: survival proteins in cancer. Exp. Cell Res. 248, 30-43.

Jacobson, M. D., Weil, M. and Raff M. C. (1997) Programmed cell death in animal development. Cell 88, 347-354.

Javelaud, D. and Besancon, F. (2001) NF-kappa B activation results in rapid inactivation of JNK in TNF alpha-treated Ewing sarcoma cells: a mechanism for the anti-apoptotic effect of NF-kappa B. Oncogene 20, 365-372.

Jiang, Y., Woronicz, J. D., Liu, W. and Goeddel, D. V. (1999) Prevention of constitutive TNF receptor 1 signaling by silencer of death domains. Science 283, 543-546.

Kajino, S., Suganuma, M., Teranishi, F., Takahashi, N., Tetsuka, T., Ohara, H., Itoh, M. and Okamoto T. (2000) Evidence that de novo protein synthesis is dispensable for anti-apoptotic effects of NF-kappaB. Oncogene 19, 2233-2239.

Kanai, M., Konda, Y., Nakajima, T. Izumi, Y., Takeuchi, T. and Chiba, T. (2001) TGF-alpha inhibits apoptosis of murine gastric pit cells through an NF-kappaB-dependent pathway. Gastroenterology 121, 56-67.
Karin, M. (1999) How NF- $\mathrm{kB}$ is activated: The role of the IKK comples. Oncogene 18, 6867-6874.

Kaufmann, S. H., Desnoyers, S., Ottaviano, Y., Davidson, N. E. and Poirier, G. G. (1993) Specific proteolytic cleavage of poly(ADP-ribose) polymerase: an early marker of chemotherapy-induced apoptosis. Cancer Res. 53, 3976-3985.

Kaufmann, S. H. (1989) Induction of endonucleolytic DNA cleavage in human acute myelogenous leukemia cells by etoposide, camptothecin, and other cytotoxic anticancer drugs: a cautionary note. Cancer Res. 49, 5870-5878.

Kawai, H., Yamada, Y., Tatsuka, M., Niwa, O., Yamamoto, K. and Suzuki, F. (1999) Down-regulation of nuclear factor kappaB is required for p53-dependent apoptosis in X-ray-irradiated mouse lymphoma cells and thymocytes. Cancer Res. 59, 6038-6041.

Kerr, J. F., Wyllie, A. H. and Currie, A. R. (1972) Apoptosis: a basic biological phenomenon with wide-ranging implications in tissue kinetics. Br. J. Cancer 26, 239-257.

Khoshnan, A., Tindell, C., Laux, I., Bae, D., Bennett, B. and Nel, A. E. (2000) The NF-kappa B cascade is important in Bcl-xL expression and for the anti-apoptotic effects of the CD28 receptor in primary human CD4+ lymphocytes. J. Immunol. 165, 1743-1754.

Kitajima, I., Soejima, Y., Takasaki, I., Beppu, H., Tokioka, T. and Maruyama, I. (1996) Ceramide-induced nuclear translocation of NF-kappa B is a potential mediator of the apoptotic response to TNF-alpha in murine clonal osteoblasts. Bone 19, 263-270.

Kolenko, V., Bloom, T., Rayman, P., Bukowski, R., Hsi, E. and Finke J. (1999) Inhibition of NF-kappa B activity in human T lymphocytes induces caspase-dependent apoptosis without detectable activation of caspase-1 and -3. J. Immunol. 163, 590-598.

Krikos, A. Laherty, C. D. and Dixit, V. M. (1992) Transcriptional activation of the tumor necrosis factor alpha-inducible zinc finger protein, A20, is mediated by kappa B elements. J. Biol. Chem. 267, 17971-17976.

Kuhnel, F., Zender, L., Paul, Y., Tietze, M. K., Trautwein, C., Manns, M. and Kubicka, S. (2000) NFkappaB mediates apoptosis through transcriptional activation of Fas (CD95) in adenoviral hepatitis. J. Biol. Chem. 275, 6421-6427.

Lallemand, F., Mazars, A., Prunier, C., Bertrand, F., Kornprost, M., Gallea, S., Roman-Roman, S., Cherqui, G. and Atfi, A. (2001) Smad7 inhibits the survival nuclear factor kappaB and potentiates apoptosis in epithelial cells. Oncogene 20, 879-884.

Lee, K.Y., Chang, W., Qiu, D., Kao, P. N. and Rosen G. D. (1999) PG490 (triptolide) cooperates with tumor necrosis factor-alpha to induce apoptosis in tumor cells. J. Biol. Chem. 274, 13451-13455.

Levkau, B., Scatena, M., Giachelli, C. M., Ross, R. and Raines, E. W. (1999) Apoptosis overrides survival signals through a caspase-mediated dominant-negative NF-kappa B loop. Nature Cell Biol. 1, 227-233.

Li, Y., Zhang, W., Mantell, L. L., Kazzaz, J. A., Fein, A. M. and Horowitz, S. (1997) Nuclear factor-kappaB is activated by hyperoxia but does not protect from cell death. J. Biol. Chem. 272, 20646-20649.

Li, Z. W., Chu, W., Hu, Y., Delhase, M., Deerinck, T., Ellisman, M., Johnson, R. and Karin, M. (1999) The IKKbeta subunit of IkappaB kinase (IKK) is essential for nuclear factor kappaB activation and prevention of apoptosis. J. Exp. Med. 189, 18391845. 
Liebermann, D. A., Hoffman, B. and Steinman, R. A. (1995) Molecular controls of growth arrest and apoptosis: p53dependent and independent pathways. Oncogene 11, 199-210.

Lin, K. I., DiDonato, J. A., Hoffmann, A. Hardwick, J. M. and Ratan, R.R. (1998) Suppression of steady-state, but not stimulus-induced NF-kappaB activity inhibits alphavirusinduced apoptosis. J. Cell Biol. 141, 1479-1487.

Lin, K. I., Lee, S. H., Narayanan, R., Baraban, J. M., Hardwick, J. M. and Ratan R. R. (1995) Thiol agents and Bcl-2 identify an alphavirus-induced apoptotic pathway that requires activation of the transcription factor NF-kappa B. J. Cell Biol. 131, 11491161.

Liu, Z. G., Hsu, H., Goeddel, D. V. and Karin, M. (1996) Dissection of TNF receptor 1 effector functions: JNK activation is not linked to apoptosis while NF-kappaB activation prevents cell death. Cell 87, 565-576.

Manna, S., Zhang, H. J., Yan T., Oberley L. W. and Aggarwal B. B. (1998) Overexpression of Mn-superoxide dismutase suppresses TNF induced apoptosis and activation of Nuclear Transcription Factor- $\mathrm{\kappa B}$ and Activated Protein-1. J. Biol. Chem. 273, 13245-13254.

Martin, S. J., O'Brien, G. A., Nishioka, W. K., McGahon, A. J., Mahboubi, A., Saido, T. C. and Green, D. R. (1995) Proteolysis of fodrin (non-erythroid spectrin) during apoptosis. J. Biol. Chem. 70, 6425-6428.

Mashima, T., Naito, M., Fujita, N., Noguchi, K. and Tsuruo, T. (1995) Identification of actin as a substrate of ICE and an ICElike protease and involvement of an ICE-like protease but not ICE in VP-16-induced U937 apoptosis. Biochem. Biophys. Res. Commun. 217,1185-1192.

McDonnell, T. J. and Korsmeyer S. J. (1991) Progression from lymphoid hyperplasia to high-grade malignant lymphoma in mice transgenic for the $t(14 ; 18)$. Nature 349, 254-256

Mukhopadhyay, A., Ni, J., Zhai, Y., Yu, G. L. and Aggarwal, B. B. (1999) Identification and characterization of a novel cytokine, THANK, $\alpha$ TNF homologue that activates apoptosis, nuclear factor-kappaB, and c-Jun NH2-terminal kinase. J. Biol. Chem. 274, 15978-15981.

Nagata, S. (1997) Apoptosis by death factor. Cell. 88, 355-365.

Nakai, M., Qin, Z. H., Chen, J. F., Wang, Y. and Chase, T. N. (2000) Kainic acid-induced apoptosis in rat striatum is associated with nuclear factor-kappaB activation. J. Neurochem. 74, 647-658.

Natoli, G., Costanzo, A., Guido, F., Moretti, F., Bernardo, A., Burgio, V. L., Agresti, C. and Levrero, M. (1998) Nuclear factor $\mathrm{kB}$-independent cytoprotective pathways originating at tumor necrosis factor receptor-associated factor 2. J. Biol. Chem. 273, 31262-31272.

Neiman, P. E., Thomas, S. J. and Loring, G. (1991) Induction of apoptosis during normal and neoplastic B-cell development in the bursa of Fabricius. Proc. Natl. Acad. Sci., USA 88, 58575861.

Okura, T., Gong, L., Kamitani, T., Wada, T., Okura, I., Wei, C. F., Chang, H.M. and Yeh, E. T. (1996) Protection against Fas/ APO-1- and tumor necrosis factor-mediated cell death by a novel protein, sentrin. J. Immunol. 157, 4277-4281.

Opipari, A. W. Jr., Hu, H. M., Yabkowitz, R. and Dixit, V. M. (1992) The A20 zinc finger protein protects cells from tumor necrosis factor cytotoxicity. J. Biol. Chem. 267, 12424-12427.

Oya, M., Ohtsubo, M., Takayanagi, A., Tachibana, M., Shimizu,
N. and Murai, M. (2001) Constitutive activation of nuclear factor-kappaB prevents TRAIL-induced apoptosis in renal cancer cells. Oncogene 20, 3888-3896.

Packham, G., Lahti, J. M., Fee B. E., Gawn, J. M., CoustanSmith, E., Campana, D., Doughlas, I., Kidd, V. J., Ghosh, S. and Cleveland, J. L. (1997) Fas activates NF- $\mathrm{KB}$ and induces apoptosis in T-cell lines by signaling pathways distinct from those induced by TNF- $\alpha$. Cell Death Differ. 4, 130-139.

Pahl, H. L. (1999) Activators and target genes of Rel/NF- $\kappa B$ transcription factors. Oncogene 18, 6853-6866.

Qin, J. Z., Chaturvedi, V., Denning, M. F., Choubey, D., Diaz, M. O., and Nickoloff, B. J. (1999) Role of NF-kappaB in the apoptotic-resistant phenotype of keratinocytes. J. Biol. Chem. 274, 37957-37964.

Rath, P. C. and Aggarwal, B. B. (1999) TNF-Induced Signaling in Apoptosis. J. Clinical Immunol. 19, 350-364.

Ravi, R., Bedi, A., Fuchs, E. J. and Bedi, A. (1998) CD95 (Fas)induced caspase-mediated proteolysis of NF-kappaB. Cancer Res. 58, 882-886.

Reuther, J. Y. and Baldwin, A. S. Jr. (1999) Apoptosis promotes a caspase-induced amino-terminal truncation of IkappaBalpha that functions as a stable inhibitor of NF-kappaB. J. Biol. Chem. 274, 20664-20670.

Romashkova, J. A. and Makarov, S. S. (1999) NF-kappaB is a target of AKT in anti-apoptotic PDGF signaling [see comments]. Nature 401, 86-90.

Scaffidi, C., Schmitz, I., Krammer, P. H. and Peter, M. E. (1999) The role of c-FLIP in modulation of CD95-induced apoptosis. J. Biol. Chem. 274, 1541-1548.

Schneider, A., Martin-Villalba, A., Weih, F., Vogel, J., Wirth, T. and Schwaninger, M. (1999) NF-kappaB is activated and promotes cell death in focal cerebral ischemia. Nature Med. 5, 554-559.

Shao, R., Hu, M. C., Zhou, B. P., Lin, S. Y., Chiao, P. J., von Lindern, R. H., Spohn, B. and Hung, M. C. (1999) E1A sensitizes cells to tumor necrosis factor-induced apoptosis through inhibition of IkappaB kinases and nuclear factor kappaB activities. J. Biol. Chem. 274, 21495-21498.

Shao, R., Karunagaran, D., Zhou, B. P., Li, K., Lo, S. S., Deng, J., Chiao, P. and Hung, M. C. (1997) Inhibition of nuclear factor-kappaB activity is involved in E1A-mediated sensitization of radiation-induced apoptosis. J. Biol. Chem. 272, 32739-32742.

Sheikh, M. S. and Fornace, A. J. Jr. (2000) Death and decoy receptors and p53-mediated apoptosis. Leukemia 14, 15091513.

Shibata, S., Kyuwa, S., Lee, S. K. and Goto, N. (1994) Apoptosis induced in mouse hepatitis virus-infected cells by a virus specific CD8+ cytotoxic T-lymphocyte clone. J. Virol. 68, 7540-7545.

Slater, A. F. G., Kimland, M., Jiang, S. A. and Orrenius, S. (1995) Constitutive nuclear NF-kappaB/rel DNA-binding activity of rat thymocytes is increased by stimuli that promote apoptosis, but not inhibited by pyrrolidine dithiocarbamate. Biochem. J. 312, 833-838.

Smith, C. A., Farrah, T. and Goodwin, R. G. (1994) The TNF receptor superfamily of cellular and viral proteins: activation, co-stimulation, and death. Cell 76, 959-962.

Song, Q., Lees-Miller, S. P., Kumar, S., Zhang, Z., Chan, D. W., Smith, G. C., Jackson, S. P., Alnemri, E. S., Litwack, G., 
Khanna, K. K. and Lavin, M. F. (1996) DNA-dependent protein kinase catalytic subunit: a target for an ICE-like protease in apoptosis. EMBO J. 15, 3238-3246.

Stambolic, V., Mak, T. W. and Woodgett, J. R. (1999) Modulation of cellular apoptotic potential: contributions to oncogenesis. Oncogene 18, 6094-6103.

Stark, L. A., Din, F. V., Zwacka, R. M. and Dunlop, M. G. (2001) Aspirin-induced activation of the NF-kappaB signaling pathway: a novel mechanism for aspirin-mediated apoptosis in colon cancer cells. FASEB J. 15, 1273-1275.

Stehlik, C., de Martin, R., Kumabashiri, I., Schmid, J. A., Binder, B. R. and Lipp, J. (1998) Nuclear factor (NF)-kappaBregulated X-chromosome-linked iap gene expression protects endothelial cells from tumor necrosis factor alpha-induced apoptosis. J. Exp. Med. 188, 211-216.

Sugiyama, H., Savill, J. S., Kitamura, M., Zhao, L. and Stylianou, E. (1999) Selective sensitization to tumor necrosis factor-alphainduced apoptosis by blockade of NF-kappaB in primary glomerular mesangial cells. J. Biol. Chem. 274, 19532-19537.

Susin, S. A., Zamzami, N. and Kroemer, G. (1998) Mitochondria as regulators of apoptosis: doubt no more. Biochim. Biophys. Acta 1366, 151-165.

Tabata, M., Tabata, R., Grabowski, D. R., Bukowski, R. M., Ganapathi, M. K. and Ganapathi, R. (2001) Roles of NFkappaB and $26 \mathrm{~S}$ proteasome in apoptotic cell death induced by topoisomerase I and II poisons in human nonsmall cell lung carcinoma. J. Biol. Chem. 276, 8029-8036.

Takahashi, A., Alnemri, E. S., Lazebnik, Y. A., FernandesAlnemri, T., Litwack, G., Moir, R. D., Goldman, R. D., Poirier, G. G., Kaufmann, S. H. and Earnshaw, W. C. (1996) Cleavage of lamin A by Mch2 alpha but not CPP32: multiple interleukin 1 beta-converting enzyme-related proteases with distinct substrate recognition properties are active in apoptosis. Proc. Natl. Acad. Sci. USA 93, 8395-8400.

Takuma, K., Lee, E. Kidawara, M., Mori, K., Kimura., Y., Baba, A. and Matsuda, T. (1999) Apoptosis in Ca2+ reperfusion injury of cultured astrocytes: roles of reactive oxygen species and NF-kappaB activation. Eur. J.Neurosci. 11, 4204-4212.

Thompson, C. B. (1995) Apoptosis in the pathogenesis and treatment of disease. Science 267, 1456-1462.

Thornberry, N. A., Bull, H. G., Calaycay, J. R., Chapman, K. T., Howard, A. D., Kostura, M. J., Miller, D. K., Molineaux, S. M., Weidner, J. R. and Aunins, J. (1992) A novel heterodimeric cysteine protease is required for interleukin-1 beta processing in monocytes. Nature 356, 768-774.

Trauzold, A., Wermann, H., Arlt, A., Schutze, S., Schafer, H., Oestern, S., Roder, C., Ungefroren, H., Lampe, E., Heinrich, M., Walczak, H. and Kalthoff, H. (2001) CD95 and TRAIL receptor-mediated activation of protein kinase $\mathrm{C}$ and NFkappaB contributes to apoptosis resistance in ductal pancreatic adenocarcinoma cells. Oncogene 20, 4258-4269.

Van Antwerp, D. J., Martin, S. J., Kafri, T., Green, D. R. and Verma, I. M. (1996) Suppression of TNF-alpha-induced apoptosis by NF-kappaB. Science 274, 787-789.

Vollgraf, U., Wegner, M. and Richter-Landsberg, C. (1999) Activation of AP-1 and nuclear factor-kappaB transcription factors is involved in hydrogen peroxide-induced apoptotic cell death of oligodendrocytes. J. Neurochem. 73, 2501-2509.

Wallach, D. (1984) Preparations of lymphotoxin induce resistance to their own cytotoxic effect. J. Immunol. 132, 2464-2469.
Wallach, D., Varfolomeev, E. E., Malinin, N. L, Goltsev, Y. V., Kovalenko, A. V. and Boldin, M. P. (1999) Tumor necrosis factor receptor and Fas signaling mechanisms Annu. Rev. Immunol. 17, 331-367.

Wang, C. Y., Cusack, J. C. Jr., Liu, R. and Baldwin, A. S. Jr. (1999) Control of inducible chemoresistance: enhanced antitumor therapy through increased apoptosis by inhibition of NFkappaB. Nature Med. 5, 412-417.

Wang, C. Y., Mayo, M. W. and Baldwin, A. S. Jr. (1996) TNFand cancer therapy-induced apoptosis: potentiation by inhibition of NF-kappaB. Science 274, 784-787.

Wang, C. Y., Mayo, M. W., Korneluk, R. G., Goeddel, D. V. and Baldwin, A. S. Jr. (1998) NF-kappaB antiapoptosis: induction of TRAF1 and TRAF2 and c-IAP1 and c-IAP2 to suppress caspase-8 activation. Science 281, 1680-1683.

Weldon, C. B., Burow, M. E, Rolfe, K. W., Clayton, J. L., Jaffe, B. M. and Beckman, B. S. (2001) NF-kappa B-mediated chemoresistance in breast cancer cells. Surgery 130, 143-150.

Widmann, C., Gibson, S. and Johnson, G. L. (1998) Caspasedependent cleavage of signaling proteins during apoptosis. A turn-off mechanism for anti-apoptotic signals. J. Biol. Chem. 273, 7141-7147.

Winston, J. T., Coats, S. R., Wang, Y. Z. and Pledger, W. J. (1996) Regulation of the cell cycle machinery by oncogenic ras. Oncogene 12, 127-134.

Wu, M., Lee, H,. Bellas, R. E., Schauer, S. L., Arsura, M., Katz, D., FitzGerald, M. J., Rothstein, T. L., Sherr, D. H. and Sonenshein, G.E. (1996) Inhibition of NF-kappaB/Rel induces apoptosis of murine B cells. EMBO J. 15, 4682-4690.

Yamit-Hezi, A. and Dikstein, R. (1998) TAFII105 mediates activation of anti-apoptotic genes by NF-kappaB. EMBO J. 17, 5161-5169.

Yang, C, H., Murti, A., Pfeffer, S. R., Kim, J. G., Donner, D. B. and Pfeffer LM. (2001) Interferon alpha /beta promotes cell survival by activating nuclear factor kappa B through phosphatidylinositol 3-kinase and Akt. J. Biol. Chem. 276, 13756-13761.

You, M., Ku, P. T., Hrdlickova, R. and Bose, H. R. Jr. (1997) chIAP1, a member of the inhibitor-of-apoptosis protein family, is a mediator of the antiapoptotic activity of the v-Rel oncoprotein. Mol. Cell Biol. 17, 7328-7341.

Zechner, D., Craig, R., Hanford, D. S., McDonough, P. M., Sabbadini, R. A. and Glembotski, C. C. (1998) MKK6 activates myocardial cell NF-kappaB and inhibits apoptosis in a p38 mitogen-activated protein kinase-dependent manner. J. Biol. Chem. 273, 8232-8239.

Zen, K., Karsan, A., Stempien-Otero, A., Yee, E., Tupper, J., Li, X., Eunson, T., Kay, M. A. Wilson, C. B., Winn, R. K. and Harlan, J. M. (1999) NF-kappaB activation is required for human endothelial survival during exposure to tumor necrosis factor-alpha but not to interleukin-1beta or lipopolysaccharide. J. Biol. Chem. 274, 28808-28815.

Zong, W. X., Farrell, M., Bash, J. and Gelinas, C. (1997) v-Rel prevents apoptosis in transformed lymphoid cells and blocks TNFalpha-induced cell death. Oncogene 15, 971-980.

Zong, W. X., Edelstein, L. C., Chen, C., Bash, J. and Gelinas, C. (1999) The prosurvival Bcl-2 homolog Bfl-1/A1 is a direct transcriptional target of NF-kappaB that blocks TNFalphainduced apoptosis. Genes \& Dev. 13, 382-387. 